\title{
The Authority's Role and Policy in Protecting Citizens from Technology and Information Communications Dynamics During the Covid-19 Pandemic
}

\author{
Insan Tajali Nur ${ }^{1.4}$, Jamal Wiwoho ${ }^{2}$, Isharyanto ${ }^{3}$ \\ ${ }^{1.2 .3}$ Faculty of Law, Universitas Sebelas Maret, Surakarta, Indonesia \\ ${ }^{4}$ Faculty of Law, Universitas Mulawarman, Indonesia \\ insan.tn@gmail.com
}

\begin{abstract}
This study begins with the COVID-19 Pandemic's appearance in an era of rapid technological, information, and communication development that is highly intensive in the midst of society and has an effect on unforeseen social transformation. This cannot be accomplished by the present authorities' policies aimed at containing societal change, most notably improvements in technology, information, and communication during the COVID-19 pandemic. This is because the government' attitude regulates primarily health and economic matters. The authority's attitude appears to be limited, and the policy is incapable of coping with the ensuing social change. Whereas Indonesia is a God-fearing, populist, and cultured nation. This is a sort of normative legal research by emphasizing the study of literature with a particular emphasis on legal principals, legal system, jurisprudence. This study also includes descriptive research. The obvious conclusion is that the Indonesian Constitution places a premium on formal-procedural democracy. Second, the requirement for legislation to function as both a social control and a motivator of action in order to enhance the quality of welfare and justice. Through primal conceptions and a durable populist foundation to uphold positive laws and components of society's values/ethos in order to replenish authoritative policies on technology, information, and communication throughout the COVID-19 epidemic.
\end{abstract}

Keywords-Policy; Technology; Information.

\section{INTRODUCTION}

China was the first country to contract the corona virus disease in December 2019, subsequently abbreviated as COVID-19, which reached 5 million cases per month by May 2020 [1]. Indonesian authorities have implemented a number of policies to avert a pandemic, including the temporary suspension of school and work activities, limitations on religious activities, restrictions on activities in public places or facilities, entertainment, crowds, or other crowd activities.

The Indonesian authorities are unaware that the alterations brought about by the COVID19 epidemic have resulted in additional changes, including in social behavior and activities. This symptom has fueled a global trend toward interdependence for people between nations, which has been exacerbated by the COVID19 pandemic, increasing people's reliance on information and communication technologies. The prevalence of technology and knowledge in the society during the COVID19 epidemic was an unforeseen societal change that had an effect on the economy, entertainment, social media, and gatherings. While social media makes it easier for people to engage socially, it has evolved into a new tool for meeting their primary requirements [2].

The growth of communication sites during the COVID-19 Pandemic influenced the social media medium, which is a component of the content that unites the world without dividers via information and communication technology. There is an increasing amount of entertainment, educational courses, movies, chats, and online business, etc [3], Prior to the COVID19 Pandemic, it was discovered that 98 percent of children and teenagers comprehend the internet and 79.5 percent of them utilize it [4].

Internet users increased to $40 \%$ during the COVID19 pandemic, while users of video conferencing services such as Zoom, Microsoft Teams, and Telkomsel's CloudX increased by more than $443 \%$ [5]. The preceding is a result of the use of information and communication technologies in the period of globalization, which retains ideas and objectives limited to the economic sphere [6]. With industrialized countries exerting significant pressure on emerging countries to promote expansion and the State's objectives including globalization, developing countries such as Indonesia have easy access to market share and economies. Globalization's influence does not always manifest itself immediately in society, but rather through the policies of the authorities [4].

The issues that are emerging at the moment are that while widespread use of the internet/online content has a number of advantages adn disadvantages, the problem that frequently occurs in society is continuous demoralization in the form of pornography, hoaxes, identity fraud, anti-social behavior, internet addiction, and privacy concerns. and context-sensitive [7], [8]. Existing regulations have been unable to regulate every aspect of public behavior when it comes to utilizing the benefits of cyberspace [3]. 


\section{RESEARCH METHOD}

The article uses normative legal research, with a particular emphasis on library research, which includes legal principles, legal systematics, legal synchronization, and legal comparisons. Additionally, this research is descriptive analytical in nature, analyzing technology and information policies during the COVID-19 pandemic against unplanned social changes and developing appropriate formulation models to address issues related to the dynamics of social change associated with the use of technology and information during the COVID-19 Pandemic [9]

This study uses secondary data by analyzing legal materials gathered from primary, secondary, and tertiary legal sources. Secondary data are gathered through textual literary studies on books connected to scientific articles. [10] The analysis of data is qualitative in nature and is provided in a descriptive manner. Qualitative analysis is conducted by categorizing research difficulties and collective data. Qualitative analysis is described as a qualitative normative assessment used to determine the validity of data acquired from secondary sources (through literature review) and the compliance with existing norms and regulations. So that it can measure the level of influence of its application [11].

\section{FINDINGS AND DISCUSSION}

\section{Unoptimally Authority Policy on Information and Communication Technology}

Kaelan argues that the Indonesian Constitution currently empazies procedural formal democracy and in reality, that it has not enshrined the fundamental idea of the state's purpose for the benefit of the people [4] but rather favors formal-procedural democracy within a capitalist system [12].

Prasetyo quotes Jimly Assiddiqie in his journal: "For the Indonesian state, the state's objectives are stated in the preamble to the 1945 Constitution, namely: Protecting the entire Indonesian nation is the hallmark of a formal legal state; 4 things, that are a) protecting the entire Indonesian nation is the character of a formal legal state, b) improving welfare and educating the populace are the hallmarks of a material law state or welfare state; and the ultimate goal is to contribute to the maintenance of global order and social justice. Clearly, there is a statement that the authority's policy cannot be divorced from the nation's goals and participation of its citizens. Thus, policies relating to information and communication technology in Indonesia should incorporate democratic norms that refer to non-liberal discussions (power and freedom are not measured in individuals or groups only), The term deliberative literally means "consultation," "consideration," or what is referred to as "musyawarah" [13].

However, the operational basis of the authority over technology and information is still liberative/capitalist, and rules are only able to be implemented in response to problems or events, such as the current COVID19 pandemic in Indonesia. In legal terms, the law is always behind existing problems, or what is referred to as Het Recht Hink Achter De Feiten Aan, where the term Dutch legal translates as "law behind existing problems." While the provisions in question provide benefits such as protection for regular expression of opinions and selfcriticism, their weaknesses, such as their repressive nature, have not benefited economic activity and have failed to regulate ethical behavior and community dynamics in a preventive manner. [14], [15].

\section{The Optimal Information and Communication Technology Policy During Covid19 Pandemic.}

In Indonesia, the Constitution is regarded as the supreme codified text. The aforementioned document is applicable and serves as the foundation for state administration. When the constitution incorporates provisions and rights that are consistent with the values prevalent in society, it has normative value [16]. In the first paragraph of the Constitution's Preamble, it is stated that Indonesia's independence cannot be divorced from God Almighty's assistance and the lofty yearning of the nation and people to be free of foreign occupation. In connection with populism, this is a clause allowing the authority to create people-based provisions. This is consistent with M.Hatta's definition of democracy, which states that sovereignty belongs to the people, that all regulations should be based on the feelings of justice and truth that exist in the hearts of many people, and that regulations should strive to bring their people to perfection and happiness while allowing them to determine their own destiny [17].

The above statements must be a principle that specifies the fundamental rights need to protect people when technology, information, and communication are used. Through the prismatic notion (legal system collaboration), it serves as a bridge and complement to positive law and the prophetic paradigm, which is a component of the measured and framed in local wisdom / living law of the Indonesian people. The preceding is a unique notion used to shape information and technology policies during the COVID-19 pandemic [18]-[20].

If we elaborate and clarify the values conveyed by $\mathrm{M}$. Hatta, namely the unification of the Rechtsstaat and Anglo Saxon legal systems in formulating regulations and policies related to information and communication technology which includes elements of appreciation or involvement of thoughts and feelings in something that is believed (as the basis of all ethical/values). ) and underlies the behavior of a group or group of people to protect offspring, protect beliefs, protect honor, protect unity, protect social care, protect economic development and social welfare as well as sustainable morals and ethics [21].

By comparing the vision and mission of the authority's policies on controlling dynamic information and technology issues to the concepts above, the author concludes that there are still some aspects of regulations and policies that contain formal, procedural, and repressive 
values that need to be improved. Because it hostages the Indonesian people's identity and qualities to a liberalistic mindset and causes unanticipated social change to backfire on the Indonesian people [22].

Thus, assuming the above is described, policies during the COVID19 pandemic, or at any time, should be consistent with the law and legal values that exist in society and are resilient to global influences. Therefore, it is critical to underline the necessity of authorities and citizens being aware of their roles and being able to exploit technology while preserving national identity through the development of legislation and policies based on sustainable people [23]. Thus, there is no reason why the authorities do not have the view of designing policies that incorporate the aforementioned notion, because it becomes a provision for the authorities and the people to complete policies that already exist in the community's rules and values.

\section{IV.CONCLUSION}

According to the description above, the Indonesian Constitution prioritizes formal-procedural democracy, and thus has been unable to sort out the priority scale in terms of community protection and justice in obtaining technology and information during the COVID19 pandemic due to its repressive nature. The existence of law always occurs in the aftermath of a problem and only after an event occurs. Indonesian law is replete with noble and divine principles that serve as the foundation for establishing policies and administration through prismatic notions that combine positive law with indigenous wisdom in a prophetic (prophetic) paradigm. It is a rare instance of formalization in positive law in Indonesia and one way to color technology policies, information and communication during the COVID19 pandemic. It is necessary to strengthen the Legislative Function and the State's role as social control and a driver of behavior toward the national goal of improving welfare. and justice in relation to Indonesian rules and policies governing information and communication technologies.

\section{REFERENCES}

[1] Nathan Park S., "Cults and Conservatives Spread Coronavirus in South Korea," Sejong Institute., 2020. https://foreignpolicy.com/2020/02/27/coronavirus-southkorea-cults-conservatives-china/ (accessed Sep. 11, 2021).

[2] N. Kurmia, "Perkembangan Teknologi Komunikasi dan Media Baru: Implikasi terhadap Teori Komunikasi," Mediat. J. Komun., vol. 6, no. 2, pp. 291-296, 2005, doi: 10.29313/mediator.v6i2.1197.

[3] Mastur, "Implementasi Undang-Undang Nomor 11 Tahun 2008 Tentang Informasi Dan Transaksi Elektronik Sebagai Tindak Pidana Non Konvensional," Kosmik Huk., vol. 16, no. 2, p. 461, 2016.

[4] M. A. Harahap and S. Adeni, "Tren penggunaan media sosial selama pandemi di indonesia," J. Prof. FIS UNIVED, vol. 7, no. 2, pp. 13-23, 2020.

[5] Kominfo, "Riset Kominfo dan UNICEF Mengenai
Perilaku Anak dan Remaja Dalam Menggunakan Internet," Kementerian Komunikasi dan Informatika Republik Indonesia, 2014. https://www.google.com/search?q=Riset+Kominfo+dan+ UNICEF+Mengenai+Perilaku+Anak+dan+Remaja+Dalam +Menggunakan+Internet.\&oq=Riset++Kominfo++dan++ UNICEF++Mengenai++Perilaku++Anak++dan+Remaja+ +Dalam++Menggunakan++Internet.\&aqs=chrome..69i57. 1128 j0j7 \&sourceid $=$ chrome\&ie=UTF-8 $($ accessed Sep. 11 , 2021).

[6] CNN Indonesia, "Pengguna Internet Kala WFH Corona Meningkat 40 Persen di Republik Indonesia," CNN Indonesia, 2020. https://www.cnnindonesia.com/teknologi/2020040812494 7-213-491594/pengguna-internet-kala-wfh-coronameningkat-40-persen-di-ri (accessed Sep. 11, 2021).

[7] N. Mujiati and M. Yunus, "Religiusitas Media Massa Dalam Perspektif Teoantroposentris Islam," $J$. AlIjtimaiyyah, vol. 6, no. 2, p. 65, 2020, doi: 10.22373/alijtimaiyyah.v6i2.7863.

[8] S. Gumbira and J. Wiwoho, "The Implication of the Globalization on the Pancasila-Based Principles of Local Democracy in Indonesia," PADJADJARAN J. Ilmu Huk. (Journal Law), vol. 06, no. 02, pp. 361-378, 2019, doi: 10.22304/pjih.v6n2.a8.

[9] J. S. Collins, "Addition of Constitutional Question Authority in the Constitutional Court as an Effort to Protect Citizens' Constitutional Rights," J. Konstitusi, vol. 15, no. 4, p. 688, 2019.

[10] S. Soekanto, Penelitian Hukum Normatif; Suatu Tinjauan Singkat. Jakarta: Rajawali Press, 2018.

[11] S. Arikunto, Prosedur Penelitan;Suatu pendekatan. Jakarta: Rineka Cipta, 2018.

[12] Kaelan, "Inkonsistensi dan Inkoherensi dalam Undang Undang Dasar Negara Republik Indonesia Tahun 1945 Hasil Amandemen (Kajian Filosofis- Yuridis)," Badan Pengkajian Majelis Permusyarawatan Rakyat, 2017. .

[13] K. Prasetyo, "Politik Hukum Di Bidang Ekonomi Dan Pelembagaan Konsepsi Welfare State Di Dalam UndangUndang Dasar 1945," J. Konstitusi, vol. 9, no. 3, pp. 495$514,2012$.

[14] R. Safitri, "Undang-Undang Informasi dan Transaksi Elektronik Bagi Perguruan Tinggi," SALAM J. Sos. dan Budaya Syar-i, vol. 5, no. 3, pp. 197-218, 2018, doi: 10.15408/sjsbs.v5i3.10279.

[15] P. Nonet and P. Selznick, Toward Responsive Law: Law and Society in Transition. New York: Routledge dan Transaction Publisher, 1978.

[16] M. Priyanta, "Penerapan Konsep Konstitusi Hijau (Green Constitution) Di Indonesia Sebagai Tanggung Jawab Negara Dalam Perlindungan Dan Pengelolaan Lingkungan Hidup," J. Konstitusi, vol. 7, no. 4, pp. 113-130, 2010, doi: $10.31078 / \mathrm{jk}$.

[17] R. Baswir, Manifesto Ekonomi Kerakyatan. Yogyakarta: Pustaka Pelajar, 2010.

[18] M. M. MD, Membangun Politik Hukum, Menegakkan Konstitusi. Jakarta: LP3ES, 2006.

[19] H. S. Ahimsa-Putra, Paradigma Profetik Islam: Epistemologi, Etos dan Model. 2016.

[20] Fred W Riggs, Admnistration in Developing Countries: The Theory of Prismatic Society. Boston: Houghton Miffin Company, 1964.

[21] R. Noviyanti, “Analisis Diskursus Ekonomi Kerakyatan dalam Perspektif Maqasid Syariah," Iqitishodia J. Ekon. Syariah, vol. 4, no. 1, pp. 101-116, 2019.

[22] M. T. Azhary, Negara Hukum: Suatu Studi tentang Prinsip-Prinsipnya Dilihat dari segi Hukum Islam, 
Implementasinya pada Periode Negara Madinah dan Masa Kini, 1 st. Jakarta: Kencana, 2003.

[23] Biezeveld, G.A, Duurzame Milieuwetgeving. Boom Juridische Iutgevers, 2002.

[24] Kaelan, Pendidikan Pancasila, 11 st. Yogyakarta: Paradigma, 2016.

[25] M. M. Naufal and H. Jannah, "Penegakan Hukum Cyber Crime Ditinjau Dari Hukum Positif Dan Hukum Islam," Al-Mawarid J. Islam. Law, vol. 12, no. 1, pp. 69-84, 2012.

[26] S. R. Arnstein, "A Ladder of Citizen Participation," J. Am. Plan. Assoc., vol. 85, no. 1, pp. 24-34, 2019, doi: 10.1080/01944363.2018.1559388. 